\title{
The Potential Scientist's Dilemma: How the Masculine Framing of Science Shapes Friendships and Science Job Aspirations
}

\author{
G. Robin Gauthier ${ }^{1,2, *}$, Patricia Wonch Hill ${ }^{1}$, Julia McQuillan ${ }^{1}$, Amy N. Spiegel ${ }^{3}$ and \\ Judy Diamond ${ }^{4}$ \\ 1 Department of Sociology, University of Nebraska-Lincoln, 709 Oldfather Hall, Lincoln, NE 68588, USA; \\ phill3@unl.edu (P.W.H.); jmcquillan2@unl.edu (J.M.) \\ 2 Research, Evaluation and Analysis for Community Health, Department of Sociology, \\ University of Nebraska-Lincoln, 209 Benton Hall, Lincoln, NE 68588, USA \\ 3 Social and Behavioral Sciences Research Consortium, 370E Prem S. Paul Research Center at Whittier School, \\ University of Nebraska-Lincoln, 2200 Vine Street, Lincoln, NE 68583-0866, USA; aspiegel1@unl.edu \\ 4 University of Nebraska State Museum, University of Nebraska-Lincoln, 307 Morrill Hall, Lincoln, \\ NE 68588, USA; jdiamond1@unl.edu \\ * Correspondance: ggauthier3@unl.edu; Tel.: +1-402-472-2243
}

Academic Editor: Martin J. Bull

Received: 30 August 2016; Accepted: 4 February 2017; Published: 14 February 2017

\begin{abstract}
In the United States, girls and boys have similar science achievement, yet fewer girls aspire to science careers than boys. This paradox emerges in middle school, when peers begin to play a stronger role in shaping adolescent identities. We use complete network data from a single middle school and theories of gender, identity, and social distance to explore how friendship patterns might influence this gender and science paradox. Three patterns highlight the social dimensions of gendered science persistence: (1) boys and girls do not differ in self-perceived science potential and science career aspirations; (2) consistent with gender-based norms, both middle school boys and girls report that the majority of their female friends are not science kinds of people; and (3) youth with gender-inconsistent science aspirations are more likely to be friends with each other than youth with gender normative science aspirations. Together, this evidence suggests that friendship dynamics contribute to gendered patterns in science career aspirations.
\end{abstract}

Keywords: STEM (Science; Technology; Engineering \& Mathematics) education; social networks; gender; adolescence; culture; homophily

\section{Introduction}

Many science fields remain male dominated despite years of research and interventions [1,2]. Variations over time and across place, however, suggest that gender norms and systems contribute to differential representation of men and women in specific fields [3-6]. Most studies of gender disparities in science participation focus on college or post-college samples $[7,8]$ and few focus on friendship contexts, yet evidence from large population studies shows that gendered patterns in science interest exist in middle-school [9-12], a time when friendship contexts are an important component of the developmental environment [13-15]. Considerable research has focused on how youth career expectations are shaped within school and in extra-curricular contexts where peer social interaction influences activity choices, class enrollment, and consequently, career aspirations for boys and girls [16,17].

Boys and girls in the United States achieve similar average scores in math and science according to recent measures [18], yet similar ability has not translated into similar rates of confidence and 
participation by girls and boys in many science college majors and careers [19]. Why is science performance associated with career aspirations for boys but not girls? This paradox, in the context of prior research begs the question; must girls who are interested in science careers violate gender norms in order to pursue their interests? In other words, when middle school girls have high science career aspirations, are they engaging in counter-normative social behavior [20]?

This paper focuses on the friendship dimension of science career aspirations in a U.S. Midwest middle school. Theories of gender [21] and gender schemas suggest how cultural norms become part of implicit ideas of who should or should not become scientists [22,23]. Gender is a fundamental organizing principle and cognitive category in social life [24,25]. Even subtle cues that trigger masculine stereotypes about science can influence women's career interests through discouraging a sense of ambient belonging [26,27]. Like all identities, gender identity is negotiated and contested in interactions [28,29]. In their classic work, West and Zimmerman [21] highlight how people are held morally accountable for doing gender in non-normative ways. Youth "try on gender" [30] in middle school and pay more attention to peers than parents for identities [31,32]. Gender atypical youth are rated as less popular by peers and report more gender-based bullying than gender typical youth [33]. Although the implications for the social status of girls who aspire to be scientists are clear, only a few studies have examined how differential social network connections influence paths into or away from science fields [34-37].

Our contribution to this line of work is to assess whether the structure of middle school friendships reinforce these gender norms and cultural biases in favor of boys in science fields. We use standard survey and social network data to answer the following questions about middle school boys and girls: (1) Are there differences in self-perceived science potential, reported grades, and science career aspirations by gender? (2) Do boys and girls have gender-based norms about which of their friends they think of as science kinds of people? (3) Are youth with gender inconsistent science career aspirations more (or less) likely to be friends with each other than with youth who have gender-consistent science career aspirations? In answering the latter two questions, we make full use of the richness of our data.

We provide a unique way of assessing local gender norms by asking youth to assess whether or not each of their friends is "a science kind of person", thereby implicitly measuring gender associations. We know of no other studies that use assessments of friends to map the gender norms around science in a particular middle school. We further use these network data to assess whether friendship patterns may reinforce local gender norms by isolating youth who harbor gender-inconsistent science career aspirations from those who have more traditional ones. If, friendships are more common among youth who have gender-inconsistent science aspirations for any reason, then gendered norms about science go unchallenged and are reinforced, contributing to gender disparities in science engagement. Here, we focus on the possibility that the widespread cultural bias associating science with masculinity [38,39] could make science career aspirations inconsistent with femininity. If girls who have science career aspirations are transgressing gender norms, they may face limited friendship options as a result, making science career aspirations undesirable. Ultimately they may be less likely to consider a career in science, thus potentially explaining why even with higher science ability, many girls leave a science-focused path.

\subsection{Brief Overview of Theoretical Framing}

We combine social network theory on homophily [40] with a multilevel theory of gender as structure with an emphasis on the reproduction of gender inequality at the interactional level [41] to guide our study of gender and science career aspirations. Considerable social network research has documented how homophily (the tendency for individuals to form connections with others who share common socio-demographic characteristics, attitudes and/or behaviors) shapes social interactions. For example, within mixed gender settings, same gender individuals interact with each other more than different gender individuals [42]. 
Studies of inequality within organizations suggest that change needs to occur at the individual, interactional, and institutional levels to be effective [43]. Most research and interventions have focused on the individual level (e.g., leadership training, mentoring) or the institutional level (new policies), and less at the interactional level [44]. The theoretical propositions about gender [21,43] as something we "do" or "undo" [45] highlight the importance of the interactional level of gender as a social structure. We therefore offer a contribution to this line of work, focusing on friendship patterns among youth who hold similar career aspirations.

There is evidence that among adults in the United States, science is cognitively framed as masculine [25]. Below we describe a way to estimate the degree to which science is framed as masculine among middle school youth using gendered perceptions of friends. We also use patterns of friendships to capture what Risman (2004) theorizes as the interactional level of gender as structure. Risman (2004) argued that there is too little research on how gender inequality is shaped by cultural expectations during social interactions, and that most of the work that has been does has been on small samples studied through observations or interviews. She argues: "We need to shine a spotlight on the dimension of cultural interactional expectations as it is here that work needs to begin" [43]. Social network perspectives emphasize how homophily dynamics shape friendships and social capital. Theories of gender as a social structure and schemas of science as masculine suggest that science homophily will depend upon gender. We describe the gender specific meanings of science from prior research and our approach to measuring the local gendered science schemas below.

\subsection{Implicit Associations of Gender and Science}

Research suggests that girls have lower self-perceived science potential than boys [46-48] and girls are less likely than boys to translate high science grades into self-perceptions of science ability and career aspirations $[18,49]$. These perceptions are reinforced by multiple sources within the school context. Boys tend to underestimate girls' science ability [50], therefore girls must substantially outperform boys to be considered legitimate in science by others. Studies using school data suggest that teachers sometimes stereotype girls as bad at math and science, even though on average girls have similar or better grades and test scores than boys [51,52]. Teachers and peers also sometimes attribute the science achievements of girls to plodding along and achievements of boys to cleverness or raw ability $[53,54]$. Most prior work on the underestimation of girls' abilities has focused on older youth. As a result of these cultural biases disfavoring girls in science, even girls who attain high grades in science class may believe they are incapable of becoming a scientist [55]. This mechanism provides an alternative explanation for why girls are less likely to become scientists. We therefore first assess whether boys and girls who attain the same grade in science class have different levels of self-perceived science potential.

\subsection{Stereotypes of Gender and Science}

The stereotypical scientist is a gendered and racialized construct. Among youth, the stereotypical scientist is a white male [56-58]. Many textbook representations of scientists are masculine, reinforcing the perception that scientists are men [59]. As a result, girls more than boys are likely to see themselves further from the prototypical scientist and thus may be less likely to consider a future career in a science field. Stereotype matching provides a second alternative explanation for the underrepresentation of women in science fields [26,60]. If girls cannot see themselves as scientists, even if they believe they can become one, they will be less likely to aspire to have a career in science. We therefore assess whether boys and girls who have the same self-perceived science potential have different levels of science career aspirations.

\subsection{Norms and Friendships}

Peers provide a crucial context for gender socialization in adolescence. Even though on average girls have higher academic achievement than boys, girls who have high academic achievement 
can experience their success as inconsistent with femininity. Evidence from high school, college, and professional samples show that women who want to be scientists are challenging gender norms. We suspect the same is true in middle school, or at least this is a time when doing science becomes masculine, and when gender identity becomes more salient [61-63]. Several studies suggest that "doing science" also means "doing masculinity" [64-66]. The gender framing of science [4] is therefore a possible explanation for the initiation and persistence of the gendered disparity in career aspirations and outcomes [55,67]. Inasmuch as girls view "doing science" as incompatible with "doing femininity" [21], girls may see the social price of engaging in science as too high, particularly if their perceptions are reflected among their peers [68-71]. Capable girls who want to avoid potential social consequences of transgressing gender norms may not be encouraged to pursue a science career.

The relationship between masculinity and science among adolescent boys is complicated. Notions of masculinities suggest multiple ways of expressing masculinity, some more privileged than others [72]. Boys need not engage with science to be considered masculine, but when they do, they are also "doing masculinity." At the same time, appearing too engaged in the classroom and working hard (or being nerdy) is a marginal form of masculinity [73]. Because of beliefs that boys should have more innate science talent [74], boys may believe that to conform to hegemonic norms of masculinity [75], they need to denigrate working hard in science classes. Therefore, gender is relevant for science career aspirations for both boys and girls, but differently.

Boys and girls who violate gender norms likely face peer sanctioning [76,77]. Cultural ideals of masculinity and femininity influence how peers evaluate one another's actions and attitudes towards science and their alignment with conventional gender expectations [62]. Research using vignettes provide mixed evidence about how adolescents evaluate their peers knowing only about their academic ability. Luftig and Nichols [78] found girls in vignettes who were described as "good at science" had the most negative evaluations of all hypothetical students. In another vignette study, however, Händel, Vialle, and Ziegler [79] found both boys and girls were penalized for being "gifted" in science. Using chatroom data, Ziegler et al. [80] found that girls preferred to chat with boys who indicated they were "gifted," while neither boys nor girls preferred "gifted" girls.

The stereotypes that girls have less innate ability and must rely on their effort, and that science is not compatible with femininity, imply that peers are less likely to see girls as potential scientists. Therefore, we expect to find that boys and girls will be more likely to see their male friends as science kinds of people. Conversely we expect more boys and girls to see their female friends as not science kinds of people.

\subsection{Are Youth with Gender-Inconsistent Science Aspirations More Likely to Be Friends with Each Other than} with Youth with Gender Normative Science Aspirations?

To gain a better understanding of the mechanisms contributing to the paradox of higher achievement and lower science career aspirations for girls and boys, we turn to an evaluation of friendship patterns. Friendship patterns are especially important to understanding adolescent identity because peers have increasing influence throughout adolescence [81]. Friendship networks provide the social contexts (e.g., cliques in schools) in which identities are reinforced (and persist) or downplayed (and desist) [82]. Peers contribute to and monitor adolescent gender behaviors [83], academic achievement [84], and more broadly definitions of what is possible and worth doing [85]. By circumscribing what is both desirable and perceived to be possible, peers can shape attitudes and aspirations [73]. Identity claims to science may be reinforced or diminished by peer acceptance [86]. If, to avoid peer sanctioning, girls hide their interest in science from one another, they will perceive it to be non-normative in their peer groups. If this were the case, we would find that girls were consistently more likely to claim science ability than their friends are to assign one to them. Consequently, pressure to conform to perceived expectations could push girls to disengage from science, even if they were initially interested. 
Additionally, if the social boundaries between youth with divergent science career aspirations are strong (there are fewer friendships between people with different levels of science career aspirations than expected by chance), then science career aspirations are a salient social attribute $[87,88]$. The social network term for the tendency for friendships to be more common among individuals with similar demographic characteristics is homophily. The strength of homophily has been used extensively to measure social distinctions between members of different social categories [89-91] and we use homophily on science career aspirations to measure the strength of the context in which gendered norms about science are reinforced.

\subsection{Statement of the Problem}

As described above, there is a persistent paradox among youth in the United States: boys and girls have similar science achievement but boys are more likely to go into science careers than girls. As summarized, the voluminous literature on gender and science has focused only a little on middle school youth, and even less on the role of friendships in science career aspirations. We therefore ask: is there evidence that science is associated more with masculinity than femininity in middle-school? For friendships to matter, science orientations and associated career aspirations need to be salient. For boys, having high or low science career aspirations is consistent with masculinity norms. For girls, however, high science career aspirations are likely to be inconsistent with femininity. Therefore, it is possible that science career aspirations can shape friendship patterns among girls and boys, but the specific mechanisms are likely to differ because of predominant cultural beliefs that science is masculine. We use a complete social network map of a single middle school to contribute a new perspective on a long standing question.

We use data collected from 444 middle school youth in a middle school in the Midwest. The data was collected as part of a larger study examining science identity. We use cross-tabulations to explore potential explanations for differences in science career aspirations between boys and girls. We begin by analyzing whether there are gender differences in the relationship between self-reported science grades (Mostly As, As and Bs, Bs, Bs and Cs, Cs, below Cs, and a mix of As, Bs, and Cs) and self-assessed science potential (I-could, might, probably could not, or could not-become a scientist). Second, we estimate a second set of cross-tabs to ascertain whether there are gender differences in the relationship between self-assessed science potential and science career aspirations (I want a job that uses-a lot, some, a little, or no-science). Third, we examine the science attributions youth make of their male and female friends. Youth were also asked if each of their friends is "a science kind of person" ("yes", "no", "I don't know"). Finally, we use Exponential Random Graph (ERG) models to measure friendship processes that both reflect and reinforce gender differences in science career aspirations. The ERG models measure the effect of science career homophily on the probability of the presence or absence of a friendship tie between two students. We also include controls for network characteristics, individual characteristics (grades in science class), and demographic homophily, each of which provide alternative explanations for observed science-career homophily patterns. The coefficients are interpreted in the same manner as logistic regression coefficients, where each is an estimate of the influence on the probability of a friendship tie. Standard errors are produced by generating a distribution of hypothetical networks with characteristics similar to the input network [92].

\section{Results}

\subsection{Do Boys and Girls Differ in Self-Assessed Science Potential, Reported Grades, and Career Aspirations?}

We first ask whether there are gender differences in science ability that may explain perceptions that girls are less capable than boys. Similar proportions of boys and girls think they could or might be able to become a scientist (72 percent of boys and 74 percent of girls). In addition to similar self-assessed potential, boys and girls report similar science grade profiles. Most of the boys and girls report they earned As and Bs (68 percent), and few (2 percent) report below $C$ grades. The patterns in Table 1 
provide no evidence of ability differences by gender. Significantly more boys (14 percent), however, than girls (8 percent), aspire to careers with a lot of science. Therefore, there is a greater disconnect between science grades and science career aspirations for girls than for boys.

We next explore bivariate associations among the components of science identity separately for boys and girls (Table 2) to assess whether gendered patterns are consistent with the under-representation of women in science fields. Both boys and girls with higher self-reported grades in science classes are more likely to believe they "could" or "might be able to" become a scientist. This finding suggests that youth do consider their own science ability when contemplating career possibilities. We acknowledge that these responses may stem at least in part from considerations of how others might inhibit or facilitate their opportunities based on other characteristics such as socioeconomic status, gender, or race/ethnicity. Important for this paper, however, is that the association between self-reported science class grades and self-perceived ability to become a scientist does not vary by the reporting student's gender.

Table 1. Sample Descriptive Statistics by Gender with Significance Tests for Focal Variables.

\begin{tabular}{|c|c|c|c|}
\hline & Boys $(\mathrm{N}=212)$ & Girls $(\mathbf{N}=232)$ & \\
\hline \multicolumn{4}{|l|}{ Race/Ethnicity } \\
\hline White & $38 \%$ & $35 \%$ & \\
\hline Other than White & $62 \%$ & $65 \%$ & \\
\hline \multicolumn{4}{|l|}{ Grade } \\
\hline 6 th grade & $29 \%$ & $32 \%$ & \\
\hline 7 th grade & $44 \%$ & $37 \%$ & \\
\hline 8 th grade & $29 \%$ & $31 \%$ & \\
\hline \multicolumn{4}{|l|}{ Parent attended college } \\
\hline Yes & $66 \%$ & $64 \%$ & \\
\hline No & $18 \%$ & $24 \%$ & \\
\hline \multirow[t]{2}{*}{ I don't know } & $16 \%$ & $12 \%$ & \\
\hline & & & Boys-Girls $95 \%$ CI \\
\hline \multicolumn{4}{|l|}{ Self-assessed scientist potential } \\
\hline I could become a scientist & $33 \%$ & $28 \%$ & {$[-4.06,3.42]$} \\
\hline I might be able to become a scientist & $39 \%$ & $46 \%$ & {$[9.52,5.33]$} \\
\hline I probably could not become a scientist & $10 \%$ & $11 \%$ & {$[-4.31,6.86]$} \\
\hline I could not become a scientist & $9 \%$ & $7 \%$ & {$[-5.05,5.01]$} \\
\hline I don't know & $8 \%$ & $7 \%$ & {$[-8.69,7.14]$} \\
\hline \multicolumn{4}{|l|}{ Science grades } \\
\hline Mostly As & $23 \%$ & $27 \%$ & {$[-10.48,3.17]$} \\
\hline Mostly As and Bs & $39 \%$ & $36 \%$ & {$[-4.62,10.51]$} \\
\hline Mostly Bs & $5 \%$ & $5 \%$ & {$[-3.48,3.48]$} \\
\hline Mostly Bs and Cs & $5 \%$ & $9 \%$ & {$[-7.63,-0.07]$} \\
\hline Mostly Cs & $4 \%$ & $2 \%$ & {$[-0.42,4.62]$} \\
\hline Mostly below Cs & $2 \%$ & $2 \%$ & {$[-2.1,2.48]$} \\
\hline A mix of As, Bs, and Cs & $21 \%$ & $19 \%$ & {$[-3.94,8.59]$} \\
\hline \multicolumn{4}{|l|}{ Science career aspirations } \\
\hline \multicolumn{4}{|l|}{ I want a job that: } \\
\hline "uses a lot of science" & $14 \%$ & $8 \%$ & {$[1.02,10.78]$} \\
\hline "uses some science" & $25 \%$ & $25 \%$ & {$[-6.76,6.92]$} \\
\hline "uses a little science" & $19 \%$ & $23 \%$ & {$[-10.23,2.4]$} \\
\hline "does not use any science" & $13 \%$ & $15 \%$ & {$[-6.83,3.95]$} \\
\hline "I don't know" & $29 \%$ & $29 \%$ & {$[-7.67,6.63]$} \\
\hline
\end{tabular}

Notes: Confidence intervals generated through 10,000 bootstrapped samples. Bolded 95\% confidence intervals indicate a significant difference between boys and girls at the 0.05 level. Data from the Science Identity Study $\mathrm{N}=444$.

We next evaluate the second possible mechanism that may explain the under representation of women in science careers. Girls may be less likely to translate self-perceived science ability into career expectations. Thus we examine whether boys at all levels of self-assessed science potential are more likely than girls with the same self-assessed potential to aspire to a career that uses a lot of science in Table 3 below. 
Table 2. Cross-tabulation of self-reported science grades and self-perceived science potential (I "could" / "might be able to" /"probably could not" / "could not" /" I don't know if I would be able to" become a scientist) by Gender.

\begin{tabular}{|c|c|c|c|c|c|c|c|c|c|c|c|c|c|c|c|}
\hline & \multicolumn{15}{|c|}{ I___ Become a Scientist } \\
\hline & \multicolumn{3}{|c|}{ "Could" } & \multicolumn{3}{|c|}{ "Might be able to" } & \multicolumn{3}{|c|}{ "Probably could not" } & \multicolumn{3}{|c|}{ “Could not" } & \multicolumn{3}{|c|}{ “I don't know" } \\
\hline & Boys & Boys-Girls & $95 \% \mathrm{CI}$ & Boys & Boys-Girls & $95 \% \mathrm{CI}$ & Boys & Boys-Girls & $95 \% \mathrm{CI}$ & Boys & Boys-Girls & $95 \% \mathrm{CI}$ & Boys & Boys-Girls & $95 \% \mathrm{CI}$ \\
\hline \multicolumn{16}{|l|}{$\begin{array}{c}\text { My grades in } \\
\text { science class are: }\end{array}$} \\
\hline "Mostly As" & $46 \%$ & $2 \%$ & {$[-17,20]$} & $42 \%$ & $1 \%$ & {$[-17,19]$} & $4 \%$ & $-4 \%$ & {$[-13,5]$} & $4 \%$ & $-1 \%$ & {$[-8,7]$} & $4 \%$ & $2 \%$ & {$[-3,9]$} \\
\hline "As and Bs" & $36 \%$ & $7 \%$ & {$[-7,22]$} & $46 \%$ & $-14 \%$ & {$[-29,1]$} & $4 \%$ & $0 \%$ & {$[-6,6]$} & $7 \%$ & $2 \%$ & {$[-5,10]$} & $7 \%$ & $3 \%$ & {$[-3,11]$} \\
\hline "Mostly Bs" & $27 \%$ & $10 \%$ & {$[-25,46]$} & $27 \%$ & $-6 \%$ & {$[-45,34]$} & $27 \%$ & $19 \%$ & {$[-13,51]$} & $0 \%$ & $-25 \%$ & {$[-53,0]$} & $18 \%$ & $1 \%$ & {$[-31,35]$} \\
\hline "Bs and Cs" & $10 \%$ & $-10 \%$ & {$[-35,18]$} & $50 \%$ & $15 \%$ & {$[-24,29]$} & $10 \%$ & $-10 \%$ & {$[-35,19]$} & $10 \%$ & $5 \%$ & {$[-13,29]$} & $20 \%$ & $0 \%$ & {$[-31,33]$} \\
\hline "Mostly Cs" & $0 \%$ & $0 \%$ & {$[0,0]$} & $12 \%$ & $-38 \%$ & {$[-100,22]$} & $25 \%$ & $0 \%$ & {$[-67,50]$} & $38 \%$ & $13 \%$ & {$[-57,67]$} & $25 \%$ & $25 \%$ & {$[-57,67]$} \\
\hline "Mostly below Cs" & $20 \%$ & $0 \%$ & {$[-59,57]$} & $0 \%$ & $0 \%$ & {$[0,0]$} & $20 \%$ & $-20 \%$ & {$[-83,50]$} & $0 \%$ & $-40 \%$ & {$[-100,0]$} & $60 \%$ & $60 \%$ & {$[0,100]$} \\
\hline "Mixed" & $29 \%$ & $13 \%$ & {$[-4,13]$} & $33 \%$ & $-8 \%$ & {$[-28,13]$} & $20 \%$ & $-3 \%$ & {$[-20,14]$} & $16 \%$ & $11 \%$ & {$[-1,24]$} & $2 \%$ & $-14 \%$ & {$[-26,-3]$} \\
\hline
\end{tabular}

Notes: Confidence intervals generated through 10,000 bootstrapped samples. The $95 \%$ confidence intervals shown in bold indicate differences that are significant at the 0.05 level between boys and girls within the cell indicating the intersection of science grades and self-perceived science potential. Data from the Science Identity Study N $=444$. Percentages have been rounded to nearest whole value.

Table 3. Cross-tabulation of self-perceived science potential "I could" /"might be able to" /"probably could not" /"could not" / I don't know if I would" be able to become a scientist) and science career aspirations (I want a job that uses "a lot of science" /"Some science" /"a little science" /"does not use any science" /"I don't know") by Gender.

\begin{tabular}{|c|c|c|c|c|c|c|c|c|c|c|c|c|c|c|c|}
\hline \multicolumn{16}{|c|}{ I Want a Job That Uses: } \\
\hline & \multicolumn{3}{|c|}{ "A lot of science" } & \multicolumn{3}{|c|}{ "Some science" } & \multicolumn{3}{|c|}{ "A little science" } & \multicolumn{3}{|c|}{ "Does not use any science" } & \multicolumn{3}{|c|}{ “I don't know" } \\
\hline & Boys & Boys-Girls & $95 \% \mathrm{CI}$ & Boys & Boys-Girls & $95 \% \mathrm{CI}$ & Boys & Boys-Girls & $95 \%$ CI & Boys & Boys-Girls & $95 \%$ CI & Boys & Boys-Girls & $95 \% \mathrm{CI}$ \\
\hline \multicolumn{16}{|c|}{ I____ become a scientist: } \\
\hline "Could" & $28 \%$ & $14 \%$ & {$[1,28]$} & $23 \%$ & $-21 \%$ & {$[-36,-6]$} & $21 \%$ & $6 \%$ & {$[-7,19]$} & $10 \%$ & $4 \%$ & {$[-5,13]$} & $18 \%$ & $-3 \%$ & {$[-16,10]$} \\
\hline "Might be able to" & $7 \%$ & $0 \%$ & {$[-7,7]$} & $30 \%$ & $5 \%$ & {$[-8,18]$} & $23 \%$ & $-3 \%$ & {$[-15,9]$} & $8 \%$ & $-1 \%$ & {$[-9,8]$} & $31 \%$ & $-0 \%$ & {$[-14,13]$} \\
\hline "Probably could not" & $10 \%$ & $10 \%$ & {$[0,25]$} & $33 \%$ & $26 \%$ & {$[2,48]$} & $14 \%$ & $-16 \%$ & {$[-40,7]$} & $14 \%$ & $-16 \%$ & {$[-40,8]$} & $29 \%$ & $-2 \%$ & {$[-30,25]$} \\
\hline "Could not" & $0 \%$ & $0 \%$ & {$[0,0]$} & $11 \%$ & $4 \%$ & {$[-15,23]$} & $11 \%$ & $-2 \%$ & {$[-24,19]$} & $42 \%$ & $5 \%$ & {$[-29,37]$} & $37 \%$ & $-7 \%$ & {$[-41,26]$} \\
\hline "I don't know" & $6 \%$ & $0 \%$ & {$[-17,16]$} & $22 \%$ & $22 \%$ & {$[5,44]$} & $6 \%$ & $-24 \%$ & {$[-50,0]$} & $17 \%$ & $-19 \%$ & {$[-48,11]$} & $50 \%$ & $21 \%$ & {$[-13,53]$} \\
\hline
\end{tabular}

Notes: Confidence intervals generated through 10,000 bootstrapped samples. The $95 \%$ confidence intervals shown in bold indicate differences that are significant at the 0.05 level between

boys and girls within the cell indicating the intersection of science career aspirations and self-perceived science potential. Data from the Science Identity Study N = 444. Percentages have been rounded to nearest whole value. 
Gender does matter for the association between self-assessed science potential and science career aspirations (Table 3). Among youth who think they could become a scientist, more boys than girls want a job that uses "a lot of science" and more girls than boys want a job that uses "some science." A similar pattern emerges among the youth who report that they "probably could not" become a scientist. Almost twice as many girls in this group report wanting a job that uses "a little" science compared to the boys, who are more likely to report that they want a job that uses "some" science. Among those who think they "might be able to become a scientist" and those who say they "could not become a scientist", however, career aspirations are similar among boys and girls. Therefore, in part, the association between self-assessed potential and career aspirations in science differs between boys and girls.

\subsection{Do Middle School Youth Believe Their Female Friends Are Science Kinds of People?}

Up to this point, we have focused on individual dispositions and abilities relative to science careers. Identities, however, emerge through social interactions. Therefore, we now turn to analyses of gender and social networks. After each friend was listed, respondents were given a follow-up question asking whether their friend is "a science kind of person". They could answer "yes", "no" or "I don't know". In Table 4, we ask whether the respondents were more likely to view their male friends as science kinds of people than their female friends. The upper half of Table 4 reports how boys assess the science identities of their friends by their friends' gender. The first row of Table 4 shows that boys did not distinguish their male from female friends. In both cases, boys answered "Yes," that a quarter of their male and female friends ( 28 percent and 27 percent, respectively) are science kinds of people. The second row shows that boys report more of their female friends are not a science kind of person. Boys said "No" for 10 percent more of their female friends than for their male friends. The third row of Table 4 shows that about a quarter of the time boys report that they "don't know" if their male friends are science kinds of people. Thus, boys are not differentiating which of their friends are science kinds of people by gender but more boys regard their female friends as "not science kinds of people."

The lower half of Table 4 shows that girls strongly differentiate the science potential of their friends by gender. Girls answered "Yes" 41 percent of their male friends are science kinds of people and only 25 percent of their female friends are. Likewise, girls reported "No" 37 percent of their male friends are not science kinds of people compared to 53 percent of their female friends. Finally, the last row of Table 4 shows that girls are unsure how to assign 22 percent of their friends (boys and girls).

Table 4. Implicit gender associations with science based upon friend assessments of each of their friends (focal peers) as a science kind of person (or not a science kind of person) by the gender of the assessor and the gender of the focal friend.

\begin{tabular}{|c|c|c|c|c|c|}
\hline $\begin{array}{l}\text { Gender of youth } \\
\text { making assessment }\end{array}$ & Youth's assessment of their friends & Focal Boy & Focal Girl & $\begin{array}{c}\text { Focal } \\
\text { Boy-Focal Girl }\end{array}$ & $\begin{array}{l}\text { Boys-Girls } \\
95 \% \text { CI }\end{array}$ \\
\hline \multirow{4}{*}{$\begin{array}{l}\text { Boys' assessments of } \\
\text { their boy and girl friends }\end{array}$} & The friend "is a science kind of person" & $28 \%$ & $27 \%$ & $1 \%$ & {$[-6 \%, 6 \%]$} \\
\hline & The friend "is not a science kind of person" & $46 \%$ & $57 \%$ & $-11 \%$ & {$[-16 \%,-2 \%]$} \\
\hline & & $100 \%$ & $100 \%$ & & \\
\hline & Total friendship ties & 1116 & 292 & & \\
\hline \multirow{5}{*}{$\begin{array}{l}\text { Girls' assessments of } \\
\text { their boy and girl friends }\end{array}$} & The friend "is a science kind of person" & $41 \%$ & $25 \%$ & $16 \%$ & {$[7 \%, 24 \%]$} \\
\hline & The friend "is not a science kind of person" & $37 \%$ & $53 \%$ & $-16 \%$ & {$[-23 \%,-6 \%]$} \\
\hline & I don't know & $22 \%$ & $22 \%$ & $0 \%$ & {$[-9 \%, 7 \%]$} \\
\hline & & $100 \%$ & $100 \%$ & & \\
\hline & Total friendship ties & 206 & 1472 & & \\
\hline
\end{tabular}

Notes: Confidence intervals produced by 100,000 bootstrapped samples. The $95 \%$ confidence intervals shown in bold indicate significant differences between focal boys and girls. Data from the Science Identity Study $\mathrm{N}=444$. Missing data values are imputed using multiple imputation. Percentages have been rounded to nearest whole value. 
The results in Table 4 establish that both boys and girls view more of their female friends as distinctly "not" a science kind of person. Thus, being a girl and a science kind of person is not normative in this school.

\subsection{Are Youth with Gender-Inconsistent Science Aspirations More Likely to Be Friends with Each Other than} with Youth with Gender Normative Science Aspirations?

We now assess whether the structure of adolescent friendships is consistent with the reinforcement of gendered science career aspirations. We do so by making use of homophily rates to measure the extent to which science identities are reflected in the structure of adolescent friendships. Homophily measures whether social relationships (friendships) are more likely to be found among people who share a common attribute, compared to those who do not. The models in Table 5 show the relationship between science career aspiration homophily and the presence or absence of a friendship between each pair of adolescents who participated in the study. We analyze networks separately by gender, but provide a combined analysis in Appendix A1.

Table 5. Exponential random graph model of friendship ties (outcome) by network structure indicators, demographic homophily measures, and science career homophily separately by gender.

\begin{tabular}{|c|c|c|}
\hline & Boys & Girls \\
\hline \multicolumn{3}{|l|}{ Network structure indicators } \\
\hline Edges (volume of ties) & $\begin{array}{l}-6.991^{* * *} \\
(0.165)\end{array}$ & $\begin{array}{l}-6.498^{* * *} \\
(0.113)\end{array}$ \\
\hline Mutual (both nominate) & $\begin{array}{l}2.576^{* * *} \\
(0.133)\end{array}$ & $\begin{array}{l}2.882 * * * \\
(0.107)\end{array}$ \\
\hline Weighted shared friends & $\begin{array}{c}1.113^{* * *} \\
(0.062)\end{array}$ & $\begin{array}{c}1.046^{* * *} \\
(0.056)\end{array}$ \\
\hline \multicolumn{3}{|l|}{ Demographic homophily measures } \\
\hline $\begin{array}{c}\text { Same race } \\
\text { (base is different race) } \\
\text { Same grade } \\
\text { (base is different grade) } \\
\text { Same grade in science class } \\
\text { (base is different grades) } \\
\text { Same parental college attendance } \\
\text { (base is different parental college status) } \\
\text { Science career homophily } \\
\text { (base is different career aspiration) }\end{array}$ & $\begin{array}{c}0.343 * * * \\
(0.055) \\
2.462 * * * \\
(0.166) \\
0.204 * * * \\
(0.057) \\
-0.042 \\
(0.058)\end{array}$ & $\begin{array}{c}0.221 * * * \\
(0.042) \\
2.081 * * * \\
(0.116) \\
0.109 * \\
(0.049) \\
0.061 \\
(0.044)\end{array}$ \\
\hline \multicolumn{3}{|l|}{ Both youth want a career: } \\
\hline that uses "A lot" of science & $\begin{array}{l}0.327 * \\
(0.153)\end{array}$ & $\begin{array}{l}0.480 * \\
(0.196)\end{array}$ \\
\hline that uses "Some" science & $\begin{array}{l}0.225 * \\
(0.096)\end{array}$ & $\begin{array}{c}0.033 \\
(0.075)\end{array}$ \\
\hline that uses "A little" science & $\begin{array}{l}0.214 \dagger \\
(0.130)\end{array}$ & $\begin{array}{c}0.029 \\
(0.092)\end{array}$ \\
\hline that "Does not use any" science & $\begin{array}{l}0.491 * * \\
(0.145)\end{array}$ & $\begin{array}{l}-0.071 \\
(0.173)\end{array}$ \\
\hline Both youth "Do not know" & $\begin{array}{c}0.045 \\
(0.093)\end{array}$ & $\begin{array}{l}-0.018 \\
(0.080)\end{array}$ \\
\hline BIC & 5647 & 8136 \\
\hline Total number of students & 212 & 232 \\
\hline
\end{tabular}

Notes: Standard errors obtained through MCMC sampling and reported in parentheses. Missing data values are imputed using multiple imputation. Data from the Science Identity Study $\mathrm{N}=444 .+p<0.10,{ }^{*} p<0.05,{ }^{* *} p<0.01$, $* * * p<0.001$.

The first column reports the results for the network of boys. In model 1, the edge (-6.991) estimate indicates that a tie between any two randomly selected boys is unlikely. The coefficient for "same race" indicates that a tie between two boys who have the same race/ethnicity is more likely than among boys who do not share the same race/ethnicity. Friendships among boys in the same grade are also more likely, as are friendships among boys of the same race/ethnicity and boys who share the same self-reported grades in science class. Friendships are neither more nor less likely among children 
whose parents both attended/did not attend college than children whose parents had different college experiences. Boys with shared science career aspirations are more likely to be friends, but the effects are strongest at the upper and lower ends. Friendship between two boys who both want a career with "a lot" of science is 38 percent more common than between two boys with different aspirations, and friendship between two boys who want a career that uses no science is 60 percent more likely than between two with different aspirations. Looking to the second column, our results show that among girls, the only significant effect is found among those who want a career with "a lot" of science. A friendship is more (61 percent) likely between two girls who want a career with "a lot" of science relative to girls without shared science career aspirations.

\section{Discussion}

In the United States, middle-school is a time peers tend to have more influence and adults less influence on youth behaviors and identities. Youth also more explicitly "try on" identities with greater awareness of gender and consideration of accountability for gender conformity or interaction work to manage gender norm violations $[30,93]$. Early adolescence is also a time when interest in science declines, and declines more for girls than boys [12]. There are many societal and individual level reasons to support youth with interests in science to maintain science career aspirations. Much research has focused on competence, mastery, enjoyment, relevance, opportunities, and role models as avenues for sustaining science career aspirations. We extend prior work by focusing on middle-school, friends' perceptions of each other as science kinds of people to measure local norms, and the degree to which friendships match on levels of science career aspirations (homophily).

Our descriptive results show that there are no significant differences in how boys and girls think of their own capabilities, but that boys are more likely to report high science career aspirations. As expected based on gender theory, the relationship between perceived science potential and science aspirations is stronger among boys than girls. Girls and boys are less likely to see their female friends as science kinds of people, and boys are more ambivalent about their male friends. A quarter of boys are unsure if their male friends are science kinds of people, yet more than half of girls perceive their male friends as science kinds of people.

We use our network data to create a unique measure of local implicit gender science norms. We assume that if there are no implicit gender science norms, then girls and boys will be equally likely to see their boy and girl friends as science kinds of people. If, however, there are implicit gender science norms, then boys and girls will differentially see their boy and girl friends as science kinds of people. The network survey asks youth about each specific friend. The network method is similar to the implicit attitudes test $[39,94]$ in that it provides a way to capture gender bias without requiring accurate recognition and verbalization of implicit gender attitudes. We find evidence that there is an implicit gender science norm in the middle school that we studied, because friends of girls are less likely than friends of boys to see their friends as science kinds of people. We interpret this pattern of perception as indicating a norm that science is more for boys than for girls (i.e. science is masculine). Therefore, girls with high and boys with low science career aspirations are counter-normative.

In our model focusing on desire for a career with various amounts of science, we examine the association between self-assessed potential for a science career and desire for a career with a lot of science to see if girls are self-selecting out of science careers. The measure of "self-assessed science potential" has strengths and weaknesses. A strength of this measure is that it can apply to all youth, those who do and those who do not want a career in science. A weakness is that we cannot be sure if those who said that they could not become a scientist may be referring to their own limitations (not seeing themselves as having the skills or intellectual ability to be a scientist) or limitations in the world (e.g., racism, sexism, social class barriers). Future research could assess an alternative measure that asks youth if they think that they have potential to be a scientist, even if they do not aspire to a career that has a lot of science. Future research could also include measures of how much youth enjoy a 
variety of subjects, not only science. Likewise, self-reported grades in science class are an imperfect measure of science ability (most students report earning As or Bs).

Future research should also explore what middle-school aged youth think of when they hear the word "science". Prior research indicates that some science fields are more female dominated (e.g., veterinarian medicine and biology and others continue to be male dominated (e.g., physics and engineering) [6,95]. Therefore, when they hear "science", girls may imagine one field and boys another. The patterns in the current data, however, suggest that the generic term "science" is more masculine than feminine. Having established that friendships are associated with science career aspirations, future research could explore factors that contribute to opportunities to create friendships associated with science aspirations, including possible differential placement of boys and girls in higher or lower level science courses (e.g., differentiated or not).

It is possible that the association between level of desire for a career in science and friendship may be spurious. What appears to be friendships based upon science homophily could reflect other factors associated with science career aspirations. For example youth may be friends because of a shared interest in science related entertainment (e.g., Star Wars), or they could be friends through sports and just happen to share science interests. We cannot randomly assign youth to level of desire for a career in science and may not have measured and included all relevant variables. Future research could include more measures of mechanisms that lead to friendships. For example, desire for a career in science could reflect participation in out of school science activities (e.g., afterschool clubs), and friends could attend these activities together and develop interests together. Yet the latter scenario could only explain the pattern of friendships among girls, as only high science career aspirations (e.g., the counter normative condition) is associated with friendship ties. Because boys who match on any level of science career aspirations are more likely to be friends, we see more support for an association that reflects a gendered local context than a spurious association. Future studies could use an experimental approach, for example, vignettes or computer games that help youth determine science career aspirations of characters and desire for friendship with those characters. Longitudinal research could also provide insights regarding the impact of changes in science career aspirations and the maintenance, dissolution, or initiation of friendships. Whether or not the association is spurious, the consequences are the same. The pattern of friendships in this middle school inhibits exposure to counter-normative science career aspirations among girls.

Our dyadic results provide evidence that science career aspirations are salient when they are counter normative. Girls with high science career aspirations are more likely to be friends with each other than with other girls, but the pattern does not follow for other levels of science career aspirations among girls. For boys, science career aspirations are associated with friendships for boys across the spectrum, from low to high, but are the strongest for boys at the lowest level of science career aspirations. These results have two implications for girls continuing a career path towards science. First, girls who have strong science career aspirations have distinct peer groups, separate from their less-science oriented peers. Although this may have the effect of bolstering their identities, over time, social exclusion may contribute to their leaving these aspirations behind. Second, aside from these girls with strong orientations, science career aspirations do not play a large role in structuring girls friendships with other girls. An important future question to explore is if the girls who match on high science career aspirations and become friends can support sustained engagement with science better than girls who do not find friends with similar high interest in science.

Because friendships in middle school are highly gender segregated and we have a relatively small sample, we limited our analyses to gender segregated networks. We therefore report on patterns among girl only and boy only networks. In addition, we cannot tell whether youth are more likely to be friends because of their shared science aspirations, or if their shared science aspirations influence each other after friendship ties are formed. Longitudinal network studies designed to explore the direction of influence in other contexts have shown that both processes are at work (see for example Cheadle and Schwadel [96] for religiosity, Mercken et al. [97] for smoking, Knecht et al. [98] for delinquency, 
and de la Haye et al. [99] for marijuana use). We used self-reported science grades as an indicator of the feasibility of a career in science. Future research might explore additional, potentially relevant measures such as naming science as a favorite subject. We found, however, that few youth listed science when asked for their favorite subject. This study of one middle school suggests that non-normative career goals are associated with friendships among both boys and girls. This finding is consistent with our understanding of masculinities, femininity, and the development of subcultures. We suspect that youth also have implicit assumptions about race and doing science. The patterns in our survey and network data provide interesting snap shots that suggest youth notice when their peers do or do not share counter gender normative interests or behaviors. We are frustrated, however, that we do not have more rich descriptions of how youth identify likeminded peers. We want to know if youth recognize and articulate an interest in science and if they see science aspirations as consistent or inconsistent with their other identities (e.g., gender, race/ethnicity, social class, religion, athletics, etc.). Similar to the insights that Crosnoe [100] was able to generate by spending time in a High School after reaching the limits of quantitative data, our next step is to observe youth in formal and informal science related settings to see if we can identify how matching on science career aspirations occurs.

We need a better understanding of the girls who violate gender norms and have high science career aspirations. Science may be attractive to girls who are not attached to femininity or who are attracted to masculinity. We do know that girls report academic discrimination from peers for violating science and math gender norms [77]. Future research should focus on whether friendships with other girls with similar aspirations help create and reinforce science identities, or if they serve to isolate girls from their female peers. Longitudinal analyses should provide insight into whether girls influence one another's science career aspirations. It is possible that girls who might otherwise have higher science career aspirations do not, only because they would lose friends or face criticism or fewer options for friendships because of interest in something masculine.

A better understanding of the social dynamics of boys and science career aspirations also holds potential for helping to make engagement with science gender neutral. Who are the boys with lower science career aspirations? Are they more likely to be friends with each other because they do not share an interest in science and/or because they are violating the expectation that boys will be interested in science? Doing well in school, or at least trying hard at school, is feminine [101]; more work needs to be done to understand how or why some boys might reject science careers.

Clearly there are boys and girls along the full continuum of science career aspirations. There are no science ability or aspiration differences between boys' and girls' self-reports, but there are differences in their perceptions of friends. Would knowing that there are no sex differences better help youth not "frame each other by gender" [25]? Studies suggest that when youth view traits along a continuum, they are less likely to show implicit biases and hold explicit stereotypes about individuals who belong to the stereotyped group [102]. It might be the case that exposure to the continuum of science interest across diverse groups within their schools, or among youth their age, could reduce these stereotypes [103]. Social networks within schools can be harnessed to create culture change [104], and there are powerful school level forces at work that may simultaneously influence gender norms and science aspirations for girls and boys [105].

Several feminist gender scholars have struggled to theorize gender as a stratifying social structure that permeates institutions, interactions, and individual identities to make $[43,102,106]$. We contribute to these efforts by focusing on the interaction level of analysis. Network data captures prior interactions that create friendship networks. Data on youth perceptions of how much they and their friends are science kinds of people provides evidence that gendered notions of science shape relationships. The quantitative network data adds to qualitative studies of social interactions and language that engender subjects that are not inherently masculine or feminine [72].

One idea is to support informal science activities that are engaging and fun and that target diverse youth who might have low science identities. Based upon the patterns of status homophily and the importance of informal science experiences to developing science interest, motivation and 
identity [107] particularly for girls [108], settings that emphasize low-stakes fun around science may produce friendships around mutual science interest and create a context that will promote long-term confidence as a science kind of person. For example, informal science can happen through comic books with characters that give a wide variety of youth people to identify with [109]. We need more studies to discover how youth relate to the characters and may change their implicit assumptions about science and the possibility of a future science career based upon leisure materials (movies, documentaries, T.V. shows, youtubers, etc). Considerable science learning occurs through informal channels in the United States [110]. Therefore, science museums, zoos, 4-H, summer camps, afterschool clubs, and community learning centers could create spaces in which doing science is for everyone.

Gender is a fundamental organizing principal and stratifying system in the United States; it is hard to have hope that we can make gender less relevant for science engagement [41]. There are many who are trying to "unbend" gender [111]. There are pockets of progress (e.g., women in the military, running for president, NSF ADVANCE programs) and resistance (e.g., corporate boards, Wall Street, pay gaps, etc.). Our results suggest that social interactions and friendships in middle school are relevant to understanding gendered patterns of science career aspirations. Therefore, efforts to support more girls staying in science may need to go beyond individuals and institutions to facilitate interactions that promote science aspirations.

\section{Materials and Methods}

The data for these analyses are part of a larger study we conducted examining science identity in middle school youth. The data and code are available upon request from the corresponding author. The analytical sample comes from a survey administered in the winter of 2013-2014 in a single Title I middle school in the Midwest serving students from grades six to eight. All students in science classes (most of the school) were invited to participate in the study. Over 70 percent of students obtained parental consent. Students completed the survey online, although youth wrote their lists of friends on paper the day before to give the research team enough time to ensure the roster of names provided in the survey was complete. Participants could nominate up to 14 peers from any class or grade in their school.

Four hundred forty-four students completed both the substantive questionnaire and the network portion of the study. The students are predominately from racial/ethnic minority backgrounds (63 percent). There is considerable variety in the ethnic backgrounds of the students; because the school has many youth from refugee communities, there are over 30 languages spoken in the school. Because it would be important to specify homogenous subgroups, we are unable to explore the potential importance of race/ethnicity. Because prior research demonstrates that the default assumption is that a scientist is white [56], however, we control for minority status. Just over half the sample are girls ( $\mathrm{N}=212$ boys and $\mathrm{N}=232$ girls) (Table 1). We used the R package "MI" [112,113] to handle the item-level missing data by creating an imputed data set. Three students' racial identification was missing and imputations were performed based on gender grade, grades in science class, science career aspirations and self-perceived science potential.

Our data collection procedure differs from random sample selection in two ways. First, our sample contains students from a single school, rather than from a sample of schools, and second our sample contains the vast majority of those students $(>70 \%)$ rather than a small sample of those students. Re-sampling approaches are valid for data collected from either random or non-random sampling frames [114]. Kulesa, Krzywinski, Blainey, and Altman [115] recommend bootstrapping as a re-sampling method that simulates sampling variation for a single sample. Accordingly, we report confidence intervals obtained from calculating the variability obtained across 10,000 re-sampled samples of our data.

\subsection{Survey Measures}

The survey included measures of youths' self-assessed science potential (I-could, might, probably could not, could not—become a scientist), science grades (Mostly As, As and Bs, Bs, Bs and Cs, Cs, 
below Cs, and a mix of As, Bs, and Cs), and science career aspirations (I want a job that uses-a lot, some, a little, no]—science). Table 1 provides descriptive statistics by gender for each of these variables.

Youth were also asked if each of their friends is "a science kind of person" ("yes", "no", "I don't know"). We calculate the percentage of friends the youth assigned to each answer and then take the mean percentages over the entire sample. These three average science attributions sum to 100 percent for each respondent. For example, boy A has 5 male friends and he believes 3 of them are a science kind of person and 2 are not. Boy B, on the other hand, has 2 male friends and he does not think either of them are a science kind of person. If the sample consisted of only boys A and B, then boys report that 30 percent of their friends are a "a science kind of person" and 70 percent are not. The gender specific average across all youth measures how easy or hard it is for youth to think of their male and female friends as science kinds of people.

\subsection{Network Measures}

Network measures are derived from the pairwise comparisons of youths' individual responses and from structural characteristics of the friendship network. We measure science career homophily by asking whether or not the youth in each potential friendship pair wants a career that uses the same amount ("a lot", "some", "a little", "none") of science. If both youth reported they would like a career that uses the same amount of science the pair is homophilous, otherwise it is not.

We use several analyses to answer our core questions. First, we use cross-tabulation and chi-square tests to compare self-perceived science potential, reported grades, and science career aspirations by gender. We also examine associations among potential, grades, and aspirations separately for boys and girls. To measure if boys and girls have gender-based norms about which of their friends they think of as science kinds of people, we conducted cross-tabulations on the network data that measures whether friends assess their friends as science kinds of people or not science kinds of people. We describe the exponential random graph models used to answer the question: Are youth with gender-inconsistent science career aspirations more (or less) likely to be friends with each other than with youth who have gender-consistent science career aspirations.

Exponential Random Graph (ERG) models measure the effect of science career homophily on the probability of the presence or absence of a friendship tie between two youth. The coefficients are interpreted in the same manner as logistic regression coefficients, where each is a weighted estimate of the influence on the probability of a friendship tie. Standard errors are produced by generating a distribution of hypothetical networks with characteristics similar to the input network [92]. The coefficient for the variable Edges measures the volume of ties in the network. The mutual term captures that a tie from boy A to boy B is more likely to be present when boy B nominates boy A than when he does not. The term weighted shared friends captures transitivity-boy A and boy B are more likely to be friends if they have friends in common. We include the variables edges, same race, same grade, mutual, and weighted shared friends in both models to capture the basic structures of the network. For any categorical variable (science career aspirations, race, gender), the effect measures whether friendship is more likely between two youths who match, relative to a tie between two youths who do not match. We run the models separately by gender because the social ramifications of science career aspirations should play out differently for boys and girls. More practically, most friendships in middle-school are same-gender [116]. In our sample, 82 percent of nominations made by boys go to other boys and 86 percent of nominations made by girls are to other girls.

Acknowledgments: The research presented here is supported by the "Biology of Human" project funded by the National Institutes of Health through the Science Education Partnership Award Grant No. R25OD01506. The authors have access to funds for covering the costs to publish in open access. Its content is solely the responsibility of the authors and does not necessarily represent the official views of NIH. Special thanks to Jeffrey Smith and Kirk Dombrowski at UNL, Camillia Faye Matuk at NYU and Rebecca Smith at UCSF for commentary and help in this project. 
Author Contributions: Robin Gauthier, Jullia McQuillan, Trish Wonch Hill, Amy Spiegel and Judy Diamond conceived the problem and the analyses. Robin Gauthier analyzed the data and performed the analyses. Robin Gauthier, Julia McQuillan, Trish Wonch Hill and Amy Spiegel wrote the paper collaboratively. Judy Diamond provided extensive commends and recommendations. Judy Diamond and Julia McQuillan provided funding for the project and Trish Wonch Hill and Amy Spiegel (with Judy Diamond and Julia McQuillan) designed and collected the data.

Conflicts of Interest: The authors declare no conflict of interest.

\section{Appendix A}

Table A1. Exponential random graph model of friendship ties (outcome) by network structure indicators, demographic homophily measures, and science career homophily.

\begin{tabular}{|c|c|}
\hline Network Structure Indicators & \\
\hline Edges (volume of ties) & $\begin{array}{l}-7.526^{* * *} \\
(0.084)\end{array}$ \\
\hline Mutual (both nominate) & $\begin{array}{c}2.818^{* * *} \\
(0.079)\end{array}$ \\
\hline Weighted shared friends & $\begin{array}{l}1.196^{* * *} \\
(0.040)\end{array}$ \\
\hline \multicolumn{2}{|l|}{ Demographic homophily measures } \\
\hline Both boys & $0.811^{* * *}$ \\
\hline (base is different gender) & $(0.048)$ \\
\hline Both girls & $0.900^{* * *}$ \\
\hline (base is different gender) & $(0.047)$ \\
\hline Same race & $0.275^{* * *}$ \\
\hline (base is different race) & $(0.030)$ \\
\hline Same grade & $2.035^{* * *}$ \\
\hline (base is different grade) & $(0.080)$ \\
\hline Same grade in science class & $0.275^{*}$ \\
\hline (base is different grades) & $(0.035)$ \\
\hline Same parental college attendance & 0.024 \\
\hline (base is different parental college status) & $(0.033)$ \\
\hline \multicolumn{2}{|l|}{$\begin{array}{l}\text { Science career homophily among boys } \\
\text { (base is different career aspiration) }\end{array}$} \\
\hline \multicolumn{2}{|l|}{ Both youth want a career: } \\
\hline that uses "A lot" of science & $\begin{array}{l}0.303+ \\
(0.158)\end{array}$ \\
\hline that uses "Some" science & $\begin{array}{l}0.209 * \\
(0.097)\end{array}$ \\
\hline that uses "A little" science & $\begin{array}{l}0.228+ \\
(0.133)\end{array}$ \\
\hline that "Does not use any" science & $\begin{array}{l}0.472 * * \\
(0.155)\end{array}$ \\
\hline Both youth "Do not know" & $\begin{array}{c}0.040 \\
(0.095)\end{array}$ \\
\hline \multicolumn{2}{|l|}{$\begin{array}{l}\text { Science career homophily among girls } \\
\text { (base is different career aspiration) }\end{array}$} \\
\hline \multicolumn{2}{|l|}{ Both youth want a career: } \\
\hline that uses "A lot" of science & $\begin{array}{l}0.526^{* *} \\
(0.189)\end{array}$ \\
\hline that uses "Some" science & $\begin{array}{c}0.028 \\
(0.072)\end{array}$ \\
\hline that uses "A little" science & $\begin{array}{c}0.065 \\
(0.090)\end{array}$ \\
\hline that "Does not use any" science & $\begin{array}{l}-0.103 \\
(0.170)\end{array}$ \\
\hline Both youth "Do not know" & $\begin{array}{l}-0.021 \\
(0.078)\end{array}$ \\
\hline $\mathrm{BIC}$ & 17629 \\
\hline Total number of students & 444 \\
\hline
\end{tabular}

Notes: Standard errors obtained through MCMC sampling and reported in parentheses. Missing data values are imputed using multiple imputation. Data from the Science Identity Study $\mathrm{N}=444 .+p<0.10,{ }^{*} p<0.05,{ }^{* *} p<0.01$, *** $p<0.001$. 


\section{References}

1. Erin A. Cech, and Mary Blair-Loy. "Perceiving glass ceilings? Meritocratic versus structural explanations of gender inequality among women in science and technology." Social Problems 57 (2010): 371-97. [CrossRef]

2. Yu Xie, Michael Fang, and Kimberlee Shauman. "STEM Education.” Annual Review of Sociology 41 (2015): 371-97. [CrossRef] [PubMed]

3. David Beede, Tiffany Julian, David Langdon, George McKittrick, Beethika Khan, and Mark Doms. "Women in STEM: A gender gap to innovation. ESA Issue Brief\# 04-11." 2011. Available online: http:/ /www.esa.doc. gov/sites/default/files/womeninstemagaptoinnovation8311.pdf (accessed on 5 December 2014).

4. Maria Charles, and Karen Bradley. "Indulging our gendered selves? Sex segregation by field of study in 44 countries." American Journal of Sociology 114 (2009): 924-76. [CrossRef]

5. Catherine Hill, Christianne Corbett, and Andresse St Rose. Why So Few? Women in Science, Technology, Engineering, and Mathematics. Washington: ERIC, 2010.

6. Leslie Irvine, and Jenny R. Vermilya. "Gender work in a feminized profession the case of veterinary medicine." Gender E Society 24 (2010): 56-82. [CrossRef]

7. David Merolla, Richard T. Serpe, Sheldon Stryker, and P. Wesley Schultz. "Structural precursors to identity processes: The role of proximate social structures." Social Psychology Quarterly 75 (2012): 149-72. [CrossRef]

8. Amy C. Wilkins. "Race, age, and identity transformations in the transition from high school to college for Black and first-generation White men." Sociology of Education 87 (2014): 171-87. [CrossRef]

9. Sophia Catsambis. "Gender, race, ethnicity, and science education in the middle grades." Journal of Research in Science Teaching 32 (1995): 243-57. [CrossRef]

10. M. Gail Jones, Anne Howe, and Melissa J. Rua. “Gender differences in students' experiences, interests, and attitudes toward science and scientists." Science Education 84 (2000): 180-92. [CrossRef]

11. Svein Sjøberg, and Camilla Schreiner. "A comparative view on adolescents' attitudes towards science." The Culture of Science: How the Public Relates to Science across the Globe 15 (2012): 200-13.

12. Jennifer Blue, and Debra Gann. "When do girls lose interest in math and science?" Science Scope 32 (2008): 44-47.

13. Ming-Te Wang, and Jacquelynne S. Eccles. "Social support matters: Longitudinal effects of social support on three dimensions of school engagement from middle to high school." Child Development 83 (2012): 877-95. [CrossRef] [PubMed]

14. Jacquelynne S. Eccles, Sarah E. Lord, Robert W. Roeser, and Bonnie L. Barber. "The association of school transitions in early adolescence with developmental trajectories through high school." 1997. Available online: https:/ / www.researchgate.net/publication/233896223 (accessed on 26 January 2016).

15. Jacquelynne S. Eccles, and R. W. Roeser. "Schools as developmental contexts during adolescence." Journal of Research on Adolescence 21 (2011): 225-41. [CrossRef]

16. Bonnie L. Barber, Margaret R. Stone, James E. Hunt, and Jacquelynne S. Eccles. "Benefits of activity participation: The roles of identity affirmation and peer group norm sharing." Organized Activities as Contexts of Development: Extracurricular Activities, after-School and Community Programs (2005): 185-210.

17. Yariv Feniger. "The gender gap in advanced math and science course taking: Does same-sex education make a difference?" Sex Roles 65 (2010): 670-79. [CrossRef]

18. Elizabeth A. Gunderson, Gerardo Ramirez, Susan C. Levine, and Sian L. Beilock. "The role of parents and teachers in the development of gender-related math attitudes." Sex Roles 66 (2012): 153-66. [CrossRef]

19. Phillip M. Sadler, Gerhard Sonnert, Zahra Hazari, and Robert Tai. "Stability and volatility of STEM career interest in high school: A gender study." Science Education 96 (2012): 411-27. [CrossRef]

20. Julia McQuillan, and Myra Marx Ferree. "The importance of variation among husbands and the benefits of feminism for families." In Men in Families. New Jersey: Lawrence Erlbaum Associates, Inc., 1997, pp. 213-25.

21. Candace West, and Don H. Zimmerman. “Doing gender." Gender E Society 1 (1987): 125-51. [CrossRef]

22. Cecilia L. Ridgeway, and Tamar Kricheli-Katz. "Intersecting cultural beliefs in social relations gender, race, and class binds and freedoms." Gender \& Society 27 (2013): 294-318. [CrossRef]

23. Brian A. Nosek, and Frederick L. Smyth. "Implicit social cognitions predict sex differences in math engagement and achievement." American Educational Research Journal 48 (2011): 1125-56. [CrossRef]

24. Raewyn W. Connell. Gender and Power. Stanford: Stanford University Press, 1987. 
25. Cecilia L. Ridgeway. "Framed before we know it how gender shapes social relations." Gender E Society 23 (2009): 145-60. [CrossRef]

26. Sapna Cheryan, Victoria C. Plaut, Paul G. Davies, and Claude M. Steele. “Ambient belonging: How stereotypical cues impact gender participation in computer science." Journal of Personality and Social Psychology 97 (2009): 1045-60. [CrossRef] [PubMed]

27. Allison Master, Sapna Cheryan, and Andrew N. Meltzoff. "Computing whether she belongs: Stereotypes undermine girls' interest and sense of belonging in computer science." Journal of Educational Psychology 108 (2016): 424-37. [CrossRef]

28. George J. McCall, and J. L. Simmons. Identities and Interactions: An Examination of Human Associations in Everyday Life. New York: Macmillan, 1978.

29. Randal Collins. Interaction Ritual Chains. Princeton: Princeton University Press, 2004.

30. Susan L. Williams. "Trying on gender, gender regimes, and the process of becoming women." Gender E Society 16 (2002): 29-52. [CrossRef]

31. Michael Lynch, and Dante Cicchetti. "Children's relationships with adults and peers: An examination of elementary and junior high school students." Journal of School Psychology 35 (1997): 81-99. [CrossRef]

32. Wim Meeus, and Maja Deković. "Identity development, parental and peer support in adolescence: Results of a national Dutch survey." Adolescence 30 (1995): 931-44. [PubMed]

33. Jennifer A. Jewell, and Christia S. Brown. "Relations among gender typicality, peer relations, and mental health during early adolescence." Social Development 23 (2014): 137-56. [CrossRef]

34. Ronald S. Burt. "The network structure of social capital." Research in Organizational Behavior 22 (2000): 345-423. [CrossRef]

35. Julia A. Kmec, and Lindsay B. Trimble. "Does it pay to have a network contact? Social network ties, workplace racial context, and pay outcomes." Social Science Research 38 (2009): 266-78. [CrossRef] [PubMed]

36. Elizabeth H. Gorman. "Gender stereotypes, same-gender preferences, and organizational variation in the hiring of women: Evidence from law firms." American Sociological Review 70 (2005): 702-28. [CrossRef]

37. Louise Marie Roth. "The social psychology of tokenism: Status and homophily processes on Wall Street." Sociological Perspectives 47 (2004): 189-214. [CrossRef]

38. Dario Cvencek, Andrew N. Meltzoff, and Anthony G. Greenwald. "Math-Gender stereotypes in elementary school children." Child Development 82 (2011): 766-79. [CrossRef] [PubMed]

39. Huajian Cai, Yu LL Luo, Yuanyuan Shi, Yunzhi Liu, and Ziyan Yang. "Male = Science, Female = Humanities: Both implicit and explicit gender-science stereotypes are heritable." Social Psychological and Personality Science 7 (2016): 412-19. [CrossRef]

40. Miller McPherson, Lynn Smith-Lovin, and James M. Cook. “Birds of a feather: Homophily in social networks." Annual Review of Sociology 27 (2001): 415-44. [CrossRef]

41. Barbara J. Risman. Gender Vertigo: American Families in Transition. New Haven: Yale University Press, 1999.

42. J. Miller McPherson, and Lynn Smith-Lovin. "Homophily in voluntary organizations: Status distance and the composition of face-to-face groups." American Sociological Review 52 (1987): 370-79. [CrossRef]

43. Barbara J. Risman. “Gender as a social structure theory wrestling with activism." Gender $\mathcal{E}$ Society 18 (2004): 429-50. [CrossRef]

44. Monica Gaughan. "Institutional assessment of women in science: Introduction to the symposium." The Journal of Technology Transfer 31 (2006): 307-10. [CrossRef]

45. Francine M. Deutsch. “Undoing gender." Gender \& Society 21 (2007): 106-27. [CrossRef]

46. Shelley J. Correll. "Gender and the career choice process: The role of biased self-assessments." American Journal of Sociology 106 (2001): 1691-730. [CrossRef]

47. Shelley J. Correll. "Constraints into preferences: Gender, status, and emerging career aspirations." American Sociological Review 69 (2004): 93-113. [CrossRef]

48. Catherine Riegle-Crumb, Chelsea Moore, and Aida Ramos-Wada. "Who wants to have a career in science or math? Exploring adolescents' future aspirations by gender and race/ethnicity." Science Education 95 (2011): 458-76. [CrossRef] 
49. James D. Lee. "More than ability: Gender and personal relationships influence science and technology involvement." Sociology of Education 75 (2002): 349-73. [CrossRef]

50. Daniel Z. Grunspan, Sarah L. Eddy, Sara E. Brownell, Benjamin L. Wiggins, Alison J. Crowe, and Steven M. Goodreau. "Males under-estimate academic performance of their female peers in undergraduate biology classrooms." PLoS ONE 11 (2016): e0148405. [CrossRef] [PubMed]

51. Jonathan M. Kane, and Janet E. Mertz. "Debunking myths about gender and mathematics performance." Notices of the American Mathematical Society 59 (2012): 10-21. [CrossRef]

52. Daniel Voyer, and Susan D. Voyer. "Gender differences in scholastic achievement: A meta-analysis." Psychological Bulletin 140 (2014): 1174-204. [CrossRef] [PubMed]

53. Heidi B. Carlone. "The cultural production of science in reform-based physics: Girls' access, participation, and resistance." Journal of Research in Science Teaching 41 (2004): 392-414. [CrossRef]

54. Susan Jones, and Debra Myhill. “'Troublesome boys' and 'Compliant Girls': Gender identity and perceptions of achievement and underachievement." British Journal of Sociology of Education 25 (2004): 547-61. [CrossRef]

55. Catherine Riegle-Crumb, Barbara King, Eric Grodsky, and Chandra Muller. “The more things change, the more they stay the same? Prior achievement fails to explain gender inequality in entry into STEM college majors over time." American Educational Research Journal 49 (2012): 1048-73. [CrossRef] [PubMed]

56. Heidi B. Carlone, Angela W. Webb, Louise Archer, and Mandy Taylor. "What kind of boy does science? A critical perspective on the science trajectories of four scientifically talented boys." Science Education (2015): 438-64. [CrossRef]

57. Gayle A. Buck, Diandra Leslie-Pelecky, and Susan K. Kirby. "Bringing female scientists into the elementary classroom: Confronting the strength of elementary students' stereotypical images of scientists." Journal of Elementary Science Education 14 (2002): 1-8. [CrossRef]

58. Bryan A. Brown. "Discursive identity: Assimilation into the culture of science and its implications for minority students." Journal of Research in Science Teaching 41 (2004): 810-34. [CrossRef]

59. Jessica J. Good, Julie A. Woodzicka, and Lylan C. Wingfield. "The effects of gender stereotypic and counter-stereotypic textbook images on science performance." The Journal of Social Psychology 150 (2010): 132-47. [CrossRef] [PubMed]

60. Ursula Kessels. "Fitting into the stereotype: How gender-stereotyped perceptions of prototypic peers relate to liking for school subjects." European Journal of Psychology of Education 20 (2005): 309-23. [CrossRef]

61. Margaret L. Signorella, Rebecca S. Bigler, and Lynn S. Liben. “Developmental differences in children's gender schemata about others: A meta-analytic review." Developmental Review 13 (1993): 147-83. [CrossRef]

62. Lisa M. Pettitt. "Gender intensification of peer socialization during puberty." New Directions for Child and Adolescent Development 2004 (2004): 23-34. [CrossRef] [PubMed]

63. Nancy L. Galambos, David M. Almeida, and Almeida C. Petersen. "Masculinity, femininity, and sex role attitudes in early adolescence: Exploring gender intensification." Child Development 61 (1990): 1905-14. [CrossRef] [PubMed]

64. Louise Archer, Jennifer DeWitt, Jonathan Osborne, Justin Dillon, Beatrice Willis, and Billy Wong. "Not girly, not sexy, not glamorous': Primary school girls' and parents' constructions of science aspirations." Pedagogy, Culture $\mathcal{E}$ Society 21 (2013): 171-94. [CrossRef]

65. Allison J. Gonsalves. "Physics and the girly girl-There is a contradiction somewhere': Doctoral students' positioning around discourses of gender and competence in physics." Cultural Studies of Science Education 9 (2014): 503-21. [CrossRef]

66. Sarah Banchefsky, Jacob Westfall, Bernadette Park, and Charles M. Judd. “But you don't look like a scientist!: Women scientists with feminine appearance are deemed less likely to be scientists." Sex Roles 75 (2016): 95-109. [CrossRef]

67. Pamela R. Aschbacher, Erika Li, and Ellen J. Roth. "Is science me? High school students' identities, participation and aspirations in science, engineering, and medicine." Journal of Research in Science Teaching 47 (2010): 564-82. [CrossRef]

68. Louise Archer, Jennifer DeWitt, Jonathan Osborne, Justin Dillon, Beatrice Willis, and Billy Wong. "'Doing' science versus 'being' a scientist: Examining 10/11-year-old schoolchildren's constructions of science through the lens of identity." Science Education 94 (2010): 617-39. [CrossRef] 
69. Louise Archer, Jennifer DeWitt, Jonathan Osborne, Justin Dillon, Beatrice Willis, and Billy Wong. “'Balancing acts': Elementary school girls' negotiations of femininity, achievement, and science." Science Education 96 (2012): 967-89. [CrossRef]

70. Angela Calabrese Barton, Hosun Kang, Edna Tan, Tara B. O’Neill, Juanita Bautista-Guerra, and Caitlin Brecklin. "Crafting a future in science tracing middle school girls' identity work over time and space." American Educational Research Journal 50 (2013): 37-75. [CrossRef]

71. Edna Tan, Angela Calabrese Barton, Hosun Kang, and Tara O'Neill. “Desiring a career in STEM-related fields: How middle school girls articulate and negotiate identities-in-practice in science." Journal of Research in Science Teaching 50 (2013): 1143-79. [CrossRef]

72. Tristan Bridges, and Cheri J. Pascoe. "Hybrid masculinities: New directions in the sociology of men and masculinities." Social Compass 8 (2014): 246-58. [CrossRef]

73. John H. Bishop, Matthew Bishop, Lara Gelbwasser, Shanna Green, Andrew Zuckerman, Amy Ellen Schwartz, and David F. Labaree. "Nerds and freaks: A theory of student culture and norms." Brookings Papers on Education Policy 6 (2003): 141-213. [CrossRef]

74. Sarah-Jane Leslie, Andrei Cimpian, Meredith Meyer, and Edward Freeland. "Expectations of brilliance underlie gender distributions across academic disciplines." Science 347 (2015): 262-65. [CrossRef] [PubMed]

75. Raewyn W. Connell, and James W. Messerschmidt. "Hegemonic masculinity rethinking the concept." Gender \& Society 19 (2005): 829-59. [CrossRef]

76. Cheri Jo Pascoe. "'Dude, You're a Fag': Adolescent masculinity and the fag discourse." Sexualities 8 (2005): 329-46. [CrossRef]

77. Campbell Leaper, and Christia S. Brown. "Perceived experiences with sexism among adolescent girls." Child Development 79 (2008): 685-704. [CrossRef] [PubMed]

78. Richard L. Luftig, and Marci L. Nichols. "An assessment of the social status and perceived personality and school traits of gifted students by non-gifted peers." Roeper Review 13 (1991): 148-53. [CrossRef]

79. Marion Händel, Wilma Vialle, and Albert Ziegler. "Student perceptions of high-achieving classmates." High Ability Studies 24 (2013): 99-114. [CrossRef]

80. Albert Ziegler, Marina Fidelman, Marold Reutlinger, Tanja Neubauer, and Michael Heilemann. "How desirable are gifted boys for girls, and gifted girls for boys?: Results of a chatroom study." Australasian Journal of Gifted Education 19 (2010): 16-20.

81. Deborah J. Laible, Gustavo Carlo, and Marcela Raffaelli. “The differential relations of parent and peer attachment to adolescent adjustment." Journal of Youth and Adolescence 29 (2000): 45-59. [CrossRef]

82. Constance Ellwood. "Questions of classroom identity: What can be learned from codeswitching in classroom peer group talk?" The Modern Language Journal 92 (2008): 538-57. [CrossRef]

83. Robert Crosnoe, Catherine Riegle-Crumb, Sam Field, Kenneth Frank, and Chandra Muller. "Peer group contexts of girls' and boys' academic experiences." Child Development 79 (2008): 139-55. [CrossRef] [PubMed]

84. Thomas D. Cook, Yingying Deng, and Emily Morgano. "Friendship influences during early adolescence: The special role of friends' grade point average." Journal of Research on Adolescence 17 (2007): 325-56. [CrossRef]

85. Robert Crosnoe. "Friendships in childhood and adolescence: The life course and new directions." Social Psychology Quarterly, 2000, 377-91.

86. Rachael D. Robnett, and Campbell Leaper. "Friendship groups, personal motivation, and gender in relation to high school students' STEM career interest." Journal of Research on Adolescence 23 (2013): 652-64. [CrossRef]

87. Peter M. Blau. Inequality and Heterogeneity: A Primitive Theory of Social Structure. New York: Free Press, 1977, vol. 7.

88. Thomas J. Fararo, and John Skvoretz. "Unification research programs: Integrating two structural theories." American Journal of Sociology 92 (1987): 1183-209. [CrossRef]

89. Ted Mouw, and Barbara Entwisle. "Residential segregation and interracial friendship in schools." American Journal of Sociology 112 (2006): 394-441. [CrossRef]

90. Wendy Bottero, and Kenneth Prandy. "Social interaction distance and stratification." The British Journal of Sociology 54 (2003): 177-97. [CrossRef] [PubMed]

91. Jeffrey A. Smith, Miller McPherson, and Lynn Smith-Lovin. "Social distance in the United States Sex, Race, Religion, Age, and Education Homophily among Confidants, 1985 to 2004." American Sociological Review 73 (2014): 432-56. [CrossRef] 
92. Steven M. Goodreau, Susan Cassels, Danuta Kasprzyk, Daniel E. Montaño, April Greek, and Martina Morris. "Concurrent partnerships, acute infection and HIV epidemic dynamics among young adults in Zimbabwe." AIDS and Behavior 16 (2012): 312-22. [CrossRef] [PubMed]

93. Donna Eder. School Talk: Gender and Adolescent Culture. New Brunswick: Rutgers University Press, 1995.

94. Anthony G. Greenwald, Debbie E. McGhee, and Jordan L. K. Schwartz. "Measuring individual differences in implicit cognition: The implicit association test." Journal of Personality and Social Psychology 74 (1998): 1464. [CrossRef] [PubMed]

95. National Science Board. Science and Engineering Indicators 2016. Arlington: National Science Foundation, 2016.

96. Jacob E. Cheadle, and Phillip Schwadel. "The 'friendship dynamics of religion,' or the 'religious dynamics of friendship'? A social network analysis of adolescents who attend small schools." Social Science Research 41 (2012): 1198-212. [CrossRef] [PubMed]

97. Liesbeth Mercken, Christian Steglich, Philip Sinclair, Jo Holliday, and Laurence Moore. “A longitudinal social network analysis of peer influence, peer selection, and smoking behavior among adolescents in British schools." Health Psychology 31 (2012): 450-59. [CrossRef] [PubMed]

98. Andrea Knecht, Tom A. Snijders, Chris Baerveldt, Christian E. Steglich, and Werner Raub. "Friendship and delinquency: Selection and influence processes in early adolescence." Social Development 19 (2010): 494-514. [CrossRef]

99. Kaya de la Haye, Harold D. Green, David P. Kennedy, Michael S. Pollard, and Joan S. Tucker. "Selection and influence mechanisms associated with marijuana initiation and use in adolescent friendship networks." Journal of Research on Adolescence 23 (2013): 474-86. [CrossRef] [PubMed]

100. Robert Crosnoe. Fitting in, Standing out: Navigating the Social Challenges of High School to Get an Education. Cambridge: Cambridge University Press, 2011.

101. Thomas A. DiPrete, and Claudi Buchmann. The Rise of Women: The Growing Gender Gap in Education and What It Means for American Schools: The Growing Gender Gap in Education and What It Means for American Schools. New York: Russell Sage Foundation, 2013.

102. Sheri R. Levy, and Carol S. Dweck. "The impact of children's static versus dynamic conceptions of people on stereotype formation." Child Development 70 (1999): 1163-80. [CrossRef]

103. Margaret E. Tankard, and Elizabeth L. Paluck. "Norm perception as a vehicle for social change." Social Issues and Policy Review 10 (2016): 181-211. [CrossRef]

104. Elizabeth Levy Paluck, Hana Shepherd, and Peter M. Aronow. "Changing climates of conflict: A social network experiment in 56 schools." Proceedings of the National Academy of Sciences 113 (2016): 566-71. [CrossRef] [PubMed]

105. Joscha Legewie, and Thomas A. DiPrete. "The high school environment and the gender gap in science and engineering." Sociology of Education 87 (2014): 259-80. [CrossRef] [PubMed]

106. Paula England. "The gender revolution uneven and stalled." Gender E Society 24 (2010): 149-66. [CrossRef]

107. Marilyn Fenichel, and Heidi Schweingruber. Surrounded by Science: Learning Science in Informal Environments. Washington: National Academies Press, 2010.

108. Kathleen A. Fadigan, and Penny L. Hammrich. "A longitudinal study of the educational and career trajectories of female participants of an urban informal science education program." Journal of Research in Science Teaching 41 (2004): 835-60. [CrossRef]

109. Judy Diamond, Martin Powell, Angie Fox, Ann Downer-Hazell, and Charles Wood. World of Viruses. Lancaster: University of Nebraska Press, 2012.

110. National Research Council. Identifying and Supporting Productive Programs in Out-of-School Settings. Washington: National Academy Press, 2015.

111. Joan Williams. Unbending Gender: Why Family and Work Conflict and What To Do About It. New York: Oxford University Press, 2000.

112. Yu-Sung Su, Andrew Gelman, Jennifer Hill, and Masanao Yajima. "Multiple imputation with diagnostics (mi) in R: Opening windows into the Black Box." Journal of Statistical Software 45 (2011): 1-31. [CrossRef]

113. Andrew Gelman, Gary King, and Chuanhai Liu. "Not asked and not answered: Multiple imputation for multiple surveys." Journal of the American Statistical Association 93 (1999): 846-57. [CrossRef]

114. Eugene Edgington. Randomization Tests, 3rd ed. NewYork: Marcel Dekker Inc., 1995, vol. 147. 
115. Anthony Kulesa, Martin Krzywinski, Paul Blainey, and Naomi Altman. "Sampling distributions and the bootstrap: The bootstrap can be used to assess uncertainty of sample estimates." Nature Methods 12 (2015): 477-78. [CrossRef] [PubMed]

116. Scott D. Gest, Alice J. Davidson, Kelly L. Rulison, James Moody, and Janet A. Welsh. “Features of groups and status hierarchies in girls' and boys' early adolescent peer networks." New Directions for Child and Adolescent Development 118 (2007): 43-60. [CrossRef] [PubMed]

(c) (1)

(C) 2017 by the authors; licensee MDPI, Basel, Switzerland. This article is an open access article distributed under the terms and conditions of the Creative Commons Attribution (CC BY) license (http:/ / creativecommons.org/licenses/by/4.0/). 